\title{
Jules Bordet (1870-1961): Pioneer of immunology
}

Jonathan $\underline{\text { Dworkin }}{ }^{1}$, MD, Siang Yong $\underline{T a n}^{2}$, MD, JD

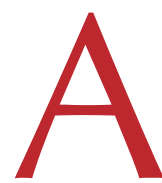

t the time when Jules Bordet began his groundbreaking experiments at the Pasteur Institute, the field of immunology was shrouded in pseudoscientific uncertainty. The lifting of this veil, through the persistent and patient process of experimentation, was Bordet's great contribution to medicine in the 20th century.

BACKGROUND Jules Bordet was born in 1870 in Soignies, a small town in Belgium. In 1874, his family moved to Brussels, and he attended a primary school in the Ecole Moyenne, where his father taught. In secondary school, Bordet became interested in chemistry, and at the age of sixteen, he enrolled into medical school at the Free University of Brussels. His early promise as a researcher earned him a scholarship to attend the Pasteur Institute in Paris. This was the beginning of a fateful relationship with Elie Metchnikoff, the father of cellular immunity and a mentor whose analytic style contrasted sharply with that of his young student.

Despite the discovery of a vaccine for smallpox by Edward Jenner in 1796, 19th century scientists still lacked the means of determining the origins of immunity. No scientific framework existed to determine what immunity consisted of or how it worked. It was Louis Pasteur, labouring eight decades after Jenner, who finally demonstrated that pathogens could be

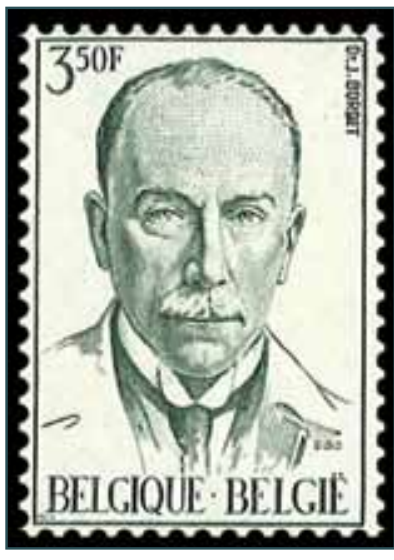

THE TRANSFORMATION OF IMMUNOLOGY

Bordet began work at the Pasteur Institute in 1894, and despite being part of Metchnikoff's lab, he was more interested in studying serum than white cells. The arrangement was an awkward one in which Bordet was compelled to put into writing his research findings regarding the role of phagocytes, although in reality, his work had little to do with phagocytosis. Bordet possessed a reserved temperament and shunned the cult of personality that then existed around the brilliant but unstable Metchnikoff. Given the contrast with his fiery Russian mentor, it was no surprise that Bordet evolved into a careful scientist, skeptical of broad principles derived from scant data and content to draw conclusions on as narrow a basis as the facts supported.

It was during this strained apprenticeship with Metchnikoff that Bordet discovered the principles that ultimately transformed immunology into a mature science. His first contribution, published in 1895, was an answer to earlier work done by Richard Pfeiffer. Pfeiffer had described a phenomenon whereby cholera bacteria introduced into the peritoneum of an immunised guinea pig were immobilised and destroyed, but the immune serum failed to kill the bacteria in a test tube. Bordet showed that serum from an immune animal could indeed kill the bacteria, even in a test tube, provided that it was fresh weakened in a laboratory and transformed into vaccines. That was the birth of immunology as a scientific discipline.

From the shoots planted by Pasteur, a great tree of research grew, eventually branching out into the various subdivisions of immunology. Elie Metchnikoff took an early step forward when he discovered phagocytosis and became the champion of the cellular theory of immunity. Emil von Behring, an ambitious and mercantile German investigator, spearheaded the next advance, demonstrating that animals inoculated with bacterial toxins developed a protective antitoxin quality in their serum. This was a property separate from any phenomenon observed in the white blood cell. In the 1890s, Behring, in conjunction with Paul Ehrlich, developed a therapeutic serum containing antitoxin to diphtheria, for which Behring won the first Nobel Prize in Medicine or Physiology in 1901. However, early enthusiasm waned when serum therapy proved to be far from ideal because of its side effects. Perhaps more importantly, the mechanism of serum immunity remained a mystery. and not heat inactivated. However, by adding a small amount of fresh serum from a nonimmune animal to the heated, inactivated serum from the immune animal, he was able to restore the latter's bacteria-killing ability. Based on these observations, Bordet concluded that the property of serum that enabled it to kill bacteria consisted of two separate components - one component was heat stable and derived from immunity acquired through previous exposure to the pathogen, while the other was heat labile and existed in all serum irrespective of immune status. The former component was the specific antibody, which was fairly well understood through the work of Behring and others, but the latter added a new dimension to the science of immunity. Bordet called this substance 'alexin'; today, it is termed' complement'.

Bordet then demonstrated that complement played a similar role in haemolysis. By injecting guinea pigs with rabbit blood, he showed that the animal's serum subsequently developed the ability to destroy rabbit red cells, and by

${ }^{1}$ Research carried out during 3rd year internal medicine residency, University of Hawaii, ${ }^{2}$ Emeritus Professor of Medicine, University of Hawaii, Honolulu, Hawaii, USA

Correspondence: Prof Tan Siang Yong, 2230 Liliha Street, Suite 104, Honolulu, HI 96817, USA. siang@hawaii.edu 
retracing the steps of his first experiment, he proved that the process of haemolysis was analogous to bacteriolysis.

Bordet's next major contribution came in 1901 when, alongside Octave Gengou, he developed the complement fixation test. Noting that complement was absorbed when antibodies bound to invading organisms, Bordet postulated that the amount of complement in a given quantity of serum would be finite. If all of the complement were consumed, none would be left to destroy any foreign red blood cells added to the mixture. Thus, by adding bacteria to a patient's serum and then adding foreign red blood cells to the mixture, Bordet could tell whether or not the patient had antibodies to the bacteria. The technique of complement fixation could also be made quantifiable by determining the number of serial dilutions at which a test remained positive, indicating the relative amount of antibody in the tested blood.

The complement fixation test became the standard basis of serologic assays used in medicine throughout the 20th century. By detecting antibody to specific pathogens, it allowed for the diagnosis of dozens of infections whose aetiologic agent was difficult to culture. An early example of this was the Wassermann reaction, developed by August von Wassermann in 1906, for the detection of syphilis. This was the first practical blood test to diagnose syphilis and proved to be a milestone in the management of the disease.

LATER WORK Famous for his work at the Pasteur Institute, Bordet returned to Brussels in 1901, destined to become the leading scientific light in his home country. He divided his time between directing the newly created Pasteur Institute of Brussels, and after 1907, teaching at the Free University. In 1906, working again with Gengou, he cultured the organism responsible for causing whooping cough in children, later named Bordetella pertussis in his honour. The Bordet-Gengou media used to culture the pathogen remained the standard media throughout the 20th century.

It was during his work in Brussels that Bordet became embroiled in a debate with Paul Ehrlich, the great German immunologist who introduced quantitative methods to the production of Behring's antiserum. Ehrlich was the originator of the side-chain theory, an early attempt to explain the principles of antibody behaviour. Bordet, because of his work with complement and haemolysis, recognised that immune phenomena were diverse, flexible and multifaceted. He thus took issue with Ehrlich's attempt to explain all humoral immunity through the rubric of free-floating receptors, which he termed 'side-chains'. At heart, Ehrlich's argument was epistemological, and Bordet was becoming increasingly exasperated by the influence of a theory that had no basis in experiment. In his understated style, he criticised Ehrlich for his "explanations that seem definite," and "schemata that appease curiosity." Ultimately, the side-chain theory crumpled and became a historical footnote, validating Bordet's skepticism of overriding explanations.

Bordet lived through both World Wars and experienced the occupation of his home country in each war. It was in 1919, while travelling in the United States to raise money for war-damaged Brussels, that Bordet received word that he was awarded the Nobel Prize. In 1924, Bordet joined a group of scientists in lobbying the League of Nations regarding the dangers of poison gas use in future wars. In the second war, despite ceding his highly public role in the Pasteur Institute of Brussels to his son Paul, Bordet was forced into hiding by pro-fascist militias. After the liberation, he joined a chorus of scientists in calling for a suspension of nuclear bomb testing. His politics, although hardly considered controversial now, is evidence that Bordet believed science must be used in the service of broadly humanistic principles. Between the end of the war and his death in 1961, Bordet's eyesight deteriorated and his ability to perform original research declined. His role as a scientific humanist became, during those final years, an important part of his legacy.

Throughout his long career, Bordet maintained an analytical style that was thoroughly modern. He was a master of inductive reasoning, using carefully designed experiments to demonstrate broader principles, but rarely speculating beyond what he could prove. Bordet, in other words, was content to admit what he did not know, a key element in his successful critique of Paul Ehrlich. In this respect, Bordet is a true descendent of Francis Bacon, the man most often credited with ridding Renaissance science of its abstract and unprovable theorising. This rigor and self-discipline allowed immunology to move beyond the mysticism of Metchnikoff and the opportunism of Behring. For these reasons, as well as the secrets uncovered by his meticulous experiments, Jules Bordet stands out as one of 20th century's preeminent medical minds.

\section{BIBLIOGRAPHY}

- Crist E. Debating humoral immunity and epistemology: the rivalry of the immunochemists Jules Bordet and Paul Ehrlich. J Hist Biol 1997; 30:321-56.

- Jules Bordet. World of Anatomy and Physiology. Online: Thomson Gale, 2006. Reproduced in Biography Resource Center. Farmington Hills: Gale, 2009.

- Jules Bordet (1870-1961). Am J Public Health Nationals Health. 1962; 52:311-2. de Kruif P. Microbe Hunters. Rahway: Harcourt, Brace and Company, 1926: 226-7.

- Laurell AB. Jules Bordet - a giant in immunology. Scand J Immunol 1990; 32:429-32.

- Magner L. A History of Medicine, 2nd ed. New York-London: Taylor \& Francis Group, 2005: 550-6, 567-8.

- Petterson A. The Nobel lectures in immunology. The Nobel Prize for Physiology or Medicine, 1919, awarded to Jules Bordet 'for his discoveries relating to immunity'. Scand J Immunol 1990; 32:425-8.

- Terris M. George Rosen and the American public health tradition. Am Public Health 1979; 69:173-6. 